\title{
Blood Parameters of Horses Maintained Over Pasture under Temperate Climatic Conditions in Kashmir
}

\author{
Syed Ishfaq Ahmad Qadri*, Imran Ahmad Ganai, Parvaiz Ahmad Dar, \\ Rather Waseem Yousuf, Manzoor Ahmad Kawa and Rayees Habib
}

S. K. colony Anantnag, SKUAST K, J\&K India

*Corresponding author

\author{
A B S T R A C T
}

\section{Keywords}

Haematological,

Healthy,

Parameters, Horses,

Farm

Article Info

Accepted:

04 June 2018

Available Online:

10 July 2018
Haematological parameters in ten apparently healthy adult horses at Mountain research Centre for Sheep and Goat, SKUAST Kashmir were examined to establish their reference values. The mean red blood cell (RBC) counts, packed cell volume (PCV), haemoglobin (Hb) concentration, white blood cell (WBC) counts, mean corpuscular volume (MCV), mean corpuscular haemoglobin $(\mathrm{MCH})$ and mean corpuscular haemoglobin concentration (MCHC) were found to be comparable with the normal values. The mean absolute values of neutrophil, eosinophil, lymphocyte, monocyte and basophil were also within the normal range. In conclusion, the $\mathrm{RBC}, \mathrm{PCV}, \mathrm{Hb}, \mathrm{WBC}, \mathrm{MCV}, \mathrm{MCH}, \mathrm{MCHC}$, neutrophils, eosinophils, lymphocytes monocytes, and basophils recorded in horses at Mountain research Centre for Sheep and Goat, SKUAST Kashmir were comparable with those values reported in other clinically healthy horses in different parts of the world.

\section{Introduction}

The horse (Equuscaballus) is a hoofed herbivorous mammal of the family Equidae. The horses are useful in Agriculture, transport, policing, games, sports and a host of others (Radostits et al., 1994). The common breeds of horses in the world are; Belgium, Arabian, Argentina, Ciollo, bard, Dangola and others. The animals suffer from a lot of bacterial, viral, fungal and parasitic diseases (Losos, 1986; Radostits et al., 1994). Hematology is a good indicator for diagnosis of various diseases in animals including horses (Schalm et al., 1975; Radostits et al., 1994).

\section{Materials and Methods}

\section{Animals}

Ten (10) apparently healthy adult horses of both sexes (seven male and three female horses) were examined at Mountain Research centre for Sheep and Goat, SKUAST K. These horses were reared on pasture grazing on the Farm. The animals were examined for various diseases, wounds or any abnormalities and those with abnormalities were excluded from the study. 


\section{Blood collection and analysis}

Five millilitres $(5 \mathrm{ml})$ of blood was collected aseptically from the jugular vein of each animal in the mornings ( $8 \mathrm{am}-9 \mathrm{am}$ ) before grazing or evenings $(5-6 \mathrm{pm})$ during grazing with the assistance of the horse attendants. Five $(5 \mathrm{ml})$ of blood collected from each animal was allowed to drain into a tube with ethylene diamine tetracetate (EDTA) for haematology.

\section{$\mathrm{Hb}, \mathrm{PCV}$, TEC, TLC, and DLC}

In the fresh blood samples the Haemoglobin (Hb) $\left(\mathrm{g} \mathrm{dL}^{-1}\right)$ was estimated by Sahli's method as recommended by Benjamin (1986). Packed Cell Volume (PCV) was determined using Wintrobe's method as described by Coles (1986). Erythrocyte count (TEC) and total leukocyte (TLC) was counted as descried by Benjamin (1986).

Differential Leukocyte Count (DLC) was done by hematocrit tube method after staining the fine smear of blood by Giemsa staining (Schalm et al., 1975).

The mean corpuscular volume (MCV), mean corpuscular haemoglobin $(\mathrm{MCH})$ and mean corpuscular haemoglobin concentration (MCHC) values were calculated (Schalm et al., 1975).

The data obtained were summarised as mean and standard error values.

Mean $\mathrm{RBC}, \mathrm{WBC}, \mathrm{PCV}$ and $\mathrm{Hb}$ values were 7.5 (Million) $/ \mu \mathrm{L}, 6.88(1000 / \mu \mathrm{L}), 42.2 \%$ and $12.8 \%$ respectively in different horses (Table 1) and haematological parameters of horses were within the normal ranges as recorded by Schalm et al., 1975 as shown in table 1 and 2.

The mean absolute DLC values were also within the normal range of values.

\section{Results and Discussion}

from the normal values reported by Schalm et al., (1975) in horses from different parts of the world. The packed cell volume (PCV) helps to determine anaemia in man and animals while $\mathrm{Hb}$ is the oxygen carrying capacity of the blood. The RBC serves as a carrier of $\mathrm{Hb}$ (Jain, 1986). The mean MCV, MCH and MCHC values observed in the present study were also in agreement with the findings of Schalm et al., 1975). The mean MCV, MCH and $\mathrm{MCH}$ values did not differ from the normal values. The upper limit value (64.70fL) for MCV was higher than the upper limit value $(58.5 \mathrm{fL})$ of the normal value of $\mathrm{MCV}$. The MCV, $\mathrm{MCH}$ and $\mathrm{MCHC}$ values assist in determining whether there is anaemia or not; and the type of anaemia (Coles, 1980; Radostits et al., 1994).

The white blood cells (WBC) or leucocytes and the absolute differential leucocyte counts (DLC) namely; neutrophils, eosinophils, lymphocytes, monocyte and basophil values were in consonance with earlier report (Schalm et al., 1975). Leucocytes generally participate in body defense against invading bacteria, viral and parasitic organisms but each is kinetically and functionally independent (Coles, 1980). The slight differences in terms of lower or upper limits of values recorded in this study when compared with the normal values may among other things be attributed to environmental, breed, age, sex and nutritional factors.

It is pertinent to note that this study was carried out in a temperate region of Kashmir where ambient temperature range between 20 and 34 degree centigrade and between -10 degree centigrade and 10 degree centigrade in winter. The findings were comparable to Schalm et al., (1975) who also made their observations from animals in the temperate region of USA. 
Table.1 Mean \pm S.E of haematological parameters of horses

\begin{tabular}{|l|l|l|l|l|l|l|l|}
\hline Animal No. & Hb\% & PCV\% & $\begin{array}{l}\text { TEC } \\
(\text { Million}) / \boldsymbol{\mu L}\end{array}$ & $\begin{array}{l}\text { TLC } \\
(\mathbf{1 0 0 0} / \boldsymbol{\mu L})\end{array}$ & $\begin{array}{l}\text { MCV } \\
(\mathbf{f L})\end{array}$ & $\begin{array}{l}\text { MCH } \\
(\mathbf{p g})\end{array}$ & $\begin{array}{l}\text { MCHC } \\
(\mathbf{g} / \mathbf{d l})\end{array}$ \\
\hline $\mathbf{4 1 6}$ & 12.5 & 40 & 7.5 & 6.5 & 53.33 & 16.66 & 31.25 \\
\hline $\mathbf{4 1 7}$ & 12.0 & 38 & 7.4 & 6.3 & 51.35 & 16.21 & 31.57 \\
\hline $\mathbf{4 1 8}$ & 13.6 & 42 & 8.0 & 7.0 & 52.50 & 17.00 & 32.38 \\
\hline $\mathbf{4 1 9}$ & 12.6 & 44 & 6.8 & 6.8 & 64.70 & 18.52 & 28.63 \\
\hline $\mathbf{4 2 0}$ & 11.8 & 38 & 6.8 & 6.0 & 55.88 & 17.35 & 31.05 \\
\hline $\mathbf{4 2 1}$ & 13.4 & 45 & 8.0 & 7.2 & 56.25 & 16.75 & 29.77 \\
\hline $\mathbf{4 2 2}$ & 13.0 & 40 & 7.8 & 7.0 & 51.28 & 16.66 & 32.50 \\
\hline $\mathbf{4 2 3}$ & 12.2 & 42 & 7.2 & 6.8 & 58.33 & 16.94 & 29.04 \\
\hline $\mathbf{4 2 4}$ & 13.4 & 45 & 7.6 & 7.4 & 59.21 & 17.63 & 29.77 \\
\hline $\mathbf{4 2 5}$ & 13.6 & 48 & 8.0 & 7.8 & 60.00 & 17.00 & 28.33 \\
\hline Mean \pm S.E & $12.8 \pm 0.68$ & $42.2 \pm 3.29$ & $7.5 \pm 0.46$ & $6.88 \pm 0.53$ & $56.19 \pm 4.34$ & $17.06 \pm 0.6430 .33 \pm 1.52$ \\
\hline
\end{tabular}

Table.2 Mean \pm S.E of differential leucocyte count of blood

\begin{tabular}{|l|l|l|l|l|l|}
\hline Animal No. & $\begin{array}{l}\text { Neutrophil } \\
\mathbf{S}(\mathbf{1 0 0 0}) / \boldsymbol{\mu} \mathbf{L}\end{array}$ & $\begin{array}{l}\text { Basophils(10 } \\
\mathbf{0 0}) / \boldsymbol{\mu L}\end{array}$ & $\begin{array}{l}\text { Eosinophils }(\mathbf{1} \\
\mathbf{0 0 0}) / \boldsymbol{\mu L}\end{array}$ & $\begin{array}{l}\text { Monocytes }(\mathbf{1 0} \\
\mathbf{0 0}) / \boldsymbol{\mu L}\end{array}$ & $\begin{array}{l}\text { Lymphocytes }(\mathbf{1} \\
\mathbf{0 0 0}) / \boldsymbol{\mu L}\end{array}$ \\
\hline $\mathbf{4 1 6}$ & 3482 & 10 & 706 & 402 & 1900 \\
\hline $\mathbf{4 1 7}$ & 3323 & 7 & 690 & 400 & 1880 \\
\hline $\mathbf{4 1 8}$ & 3660 & 10 & 755 & 440 & 2135 \\
\hline $\mathbf{4 1 9}$ & 3560 & 5 & 679 & 500 & 2056 \\
\hline $\mathbf{4 2 0}$ & 3012 & 0 & 620 & 398 & 1970 \\
\hline $\mathbf{4 2 1}$ & 3698 & 11 & 835 & 551 & 2105 \\
\hline $\mathbf{4 2 2}$ & 3589 & 9 & 789 & 610 & 2203 \\
\hline $\mathbf{4 2 3}$ & 3499 & 3 & 672 & 596 & 2030 \\
\hline $\mathbf{4 2 4}$ & 3699 & 15 & 872 & 614 & 2200 \\
\hline $\mathbf{4 2 5}$ & 3781 & 20 & 886 & 714 & 2399 \\
\hline Mean \pm S.E & $3530.3 \pm 224$ & $9 \pm 5.77$ & $750.4 \pm 91.7$ & $522.5 \pm 111.18$ & $2088.4 \pm 151.2$ \\
& .9 & & & & \\
\hline
\end{tabular}

Environment influences haematological values of animals remarkably (Coles, 1980, Miller and Campbell, 1983; Egbe-Nwiyi, 1995; Egbe-Nwiyi et al., 2007), while nutrition helps to boost the immunity of animals to withstand the effect of various diseases especially haemoparasitic types that usually attack or destroy white and red blood cells (Manston et al., 1975; Radostits et al., 1994; Egbe-Nwiyi et al., 2010). It has also been reported that age (Allen and Archer,
1973), Sex (Archer, 1959) and breed (Jain, 1986) differences affect haematological values of horses. Furthermore, Archer (1974) reported positive influence of training on red blood cell values of horses.

In conclusion, the mean values of $\mathrm{PCV}, \mathrm{Hb}$, RBC, MCV, MCH, MCHC, WBC, neutrophils, eosinophils, lymphocytes, monocytes and basophils of horses reared on Pasteur at MRCSG,SKUAST Kashmir were 
within the normal range and was comparable with values reported in clinically healthy horses in different parts of the world. However, there is the need to study in details the influence of age, sex, racing, pregnancy, lactation, nutrition, breed and weather condition on the haematological parameters of horses in temperate zone of India.

\section{Acknowledgements}

The authors appreciate the staff assistance of Dr.M.A.Pampori,Head MRCSG,SKUASTKashmir for the help in conduct of the experiment.

\section{References}

Allen, B.V. and Archer, R. K.(1973). Studies with normal erythrocytes of the English thoroughbred Horse, Equine Vet. J. 5: 135.

Benjamin, M.H., 1986. Outline of Veterinary Clinical Pathology. 3rd Edn., Iowa State University Press, Ames, USA., pp: 38-40, 61.

Archer, R. K. (1959). The normal haemograms and coagulograms of the English Thoroughred Horse. J. Comp. Path., 69: 390.

Coles, E.H., 1986. Veterinary Clinical Pathology. 4th Edn., E.B. Saunders Co., London, UK., pp: 63-6Duncan, J., and Prasse, K.W. (1977). Veterinary Laboratory Medicine, Clinical Pathology, 1st Edn., Iowa State University Press, Ames, Iowa, pp. 30-32. 9.

Egbe-Nwiyi, T.N. (1995). Effect of
Environmental temperature on haematological values of apparently healthy camels (Camelus dromedarus) in the Arid Zone of Borno. Isreal J. Vet. Med. 50(1): 35-37.

Egbe-Nwiyi, T. N. Gadaka, I. A. and Gana, S. M. (2007). The effects of seasonal changes on the haematological values of apparently healthy adult donkeys in semi-arid zone of Borno State, Nigeria. Trop. Vet. 25(2): 4851.

Egbe-Nwiyi, T. N., Aliyu, M.M. and Igbokwe, I. O.(2010): Effects of Oral Supplementation with Manganese chloride on the severity of Trypanosomabrucei and Trypanasomacongolene infections in rats. Afr. J. Biomed. Res. 13: 27-31.

Jain, N.C (1986). Schalm's Veterinary Haematology, 4th edn. Lea and Febiger, Philadelphia, USA, pp. 140-175.

Losos, G.J.(1986). Infectious Tropical diseases of domestic animals. Churchill Livingstone Inc., New York. Pp. 183-240.

Manston, R; Russell, A. M., Dew, S. M. and Payne, J. M.(1975): The influence of dietary protein upon blood composition of dairy cows. Vet. Rec. 96: 497-502.

Miller, R. L., and Campbell, R. S. F(1983). Haematology of pastured horses in tropical Queensland. Aust. Vet. J. 60: 31.

Radostits, O.M., Blood, O.C. and Gay, C.C. (1994).Veterinary Medicine, 8th Edn.,BailliereTindall, pp. 1212-1224.

Schalm, O.W., N.C. Jain and E.J. Caroll, 1975. Veterinary Hematology. 4th Edn., Lea and Febiger, Philadelphia, USA., pp: 103-104, 1136-1137.

\section{How to cite this article:}

Syed Ishfaq Ahmad Qadri, Imran Ahmad Ganai, Parvaiz Ahmad Dar, Rather Waseem Yousuf, Manzoor Ahmad Kawa and Rayees Habib. 2018. Blood Parameters of Horses Maintained Over Pasture under Temperate Climatic Conditions in Kashmir. Int.J.Curr.Microbiol.App.Sci. 7(07): 282-285. doi: https://doi.org/10.20546/ijcmas.2018.707.033 